DOI: 10.20472/IAC.2019.048.040

\author{
BAJRAWAN NUCHPRAYOOL \\ National Institute of Development Administration, Thailand
}

BANJERD SINGKANETI

National Institute of Development Administration, Thailand

\title{
ASEAN ECONOMIC DEVELOPMENT: IMPACTS AND ADAPTATION FOR THAI LOCAL ADMINISTRATIVE ORGANIZATIONS
}

\begin{abstract}
:
Economic development is influenced by domestic development and international obligations. Local administrative organizations may have to bear the effects of various aspects of economic development.

Current fundamental problems concerning the role, power and duties of the Local administrative organizations result from the separation of governance to the central, the regional, and the local administrative organizations. Local administrative organizations are again divided into provincial administrative organizations, municipalities, and sub-district administrative organizations. The fundamental issues concerning Thai governance, especially in any specific province, is the separation of roles, powers, duties, budget, and personnel of organizations in a manner in which they are dispersed through the various governmental offices at the department level based on their missions and duties. Concurrently, the administration at local levels has overlapping jurisdiction between provincial administrative organizations and the municipality, and sub-district administrative organizations. The nature of these problematic issues is one that currently exists; however, another dimension is the state of global transformation which poses an additional challenge for the role, power, and duties of Local administrative organizations.

This study aims at examining the impacts and adaptation for Thai local administrative organizations resulting from the economic development of ASEAN. The study is separated into three parts: 1) Thailand and economic development in ASEAN; 2 ) the impact of the local administrative organization toward economic development and 3) analysis and recommendations for Thai local administrative organizations.
\end{abstract}

\section{Keywords:}

local administrative organization, local governance, Economic Development, ASEAN Economic Community

JEL Classification: K23, K19, L38 


\section{Introduction}

Economic development is an important factor for local, national and global development. The changing economic scenario directly results in the interaction between people, institutional, and social factors which develop in various forms such as population welfare, trade and investment, environment, politics, and international relations. In addition, it changes other dimensions such as internal and foreign politics and technological development. Thailand is part of a global economic system which needs to rely on and compete with other countries to survive and improve the economy. From the ranking of the size and standard of economic development of Thailand by using Gross domestic product (GDP), this calculation uses the price of the products and services in the United State as a base for calculation and uses the US dollar to compare the GDP standard with that of 32 countries around the world. Its ratio is up to $85 \%$. In 2016 , Thailand was ranked 24th while the GDP was 387 thousand million dollars for a population of 67.7 million. The income per person was 14,354 dollars. (U.S.News, 2017) Among developing Asian economies, Thailand ranked 2 nd with the production value inside the country going up to 387,252 million dollars and tending to increase every year. That is relevant to the result of the ranking of competitive ability of Thailand. According to IMD, in 2015-2016 Thailand ranked 30th out of 61 nations around the world. (Office of the National Economics and Social Development Council, 2017)

This economic development affects the area improvement especially the style of local administrative organizations as they need to know what has been changing. Thus, to study the changing economy that affects the preparation of the organization, one needs to study Thailand's role in driving economic development in ASEAN (1) which affects the local governmental organization in many aspects (2) and the adjustment for this change (3).

\section{Thailand and economic development in ASEAN}

Nowadays, Thailand has two key aspects regarding the current economic development: the framework for development from international cooperation or agreements and the country's internal developmental mechanisms. Considering international cooperation, we find that the major factor contributing to development is the cooperation framework within the ASEAN Economic Community (AEC). This masterplan involves the cooperation of the ASEAN Free Trade Area (AFTA) and development plans for the Greater Mekong Subregion (GMS). This has led to the development of the Eastern Economic Corridor (EEC) policies and the Twelfth National Economic and Social Development Plan as well as state policies towards economic development which affect the local administrative organizations.

\subsection{ASEAN Economic Community (AEC)}

Economic development is created by the cooperation of AEC countries. AEC is a collaborative effort between 10 countries within the region to provide joint economic benefit, the ability to negotiate with competitive nations, and cooperation in import-export within ASEAN. The ASEAN Free Trade Area (AFTA) is an agreement within the region to open up trading of goods to countries with close relations with Thailand and is Thailand's foremost export market. Exporters will receive the maximum tax benefits from the Free Trade Area (FTA) agreement. (Office of 
Industrial Economics, 2012) ASEAN has set their strategy towards the ASEAN Economic Community based on the Declaration of ASEAN Concord II (Bali Concord II) which has four aspects including creating a single market and production base, developing regional capacity for maximum competition, developing the economy regionally on an equal footing, and the integration of the region with the global economy. Member States have jointly taken measures to increase the competitiveness of ASEAN by instituting various important measures, namely, the abolition of tariffs, the abolition of non-tariff trade barriers, stipulating ASEAN standards, improving Rules of Origin of goods, facilitating trade, the harmonization of customs procedures to reduce transactional costs, the harmonization of standards and the reduction of technical barriers towards trade, and liberalization of services and investment in industries and services which are open to ASEAN member countries. (Department of ASEAN Affairs, 2009)

\subsection{Greater Mekong Subregion (GMS)}

In addition to the overall cooperation of ASEAN, the six countries of GMS have developed a strategic plan for economic cooperation in a complementary manner by using financial and technical support from the Asian Development Bank (ADB) as the driving force in the development of the region. Starting with the connectivity of infrastructure, particularly in transportation and energy, it aims to develop the capacity to compete by reducing the initial cost of cross-border trade. Transportation and manufacturing promotes cross-border investment, enhancing competitiveness by promoting financial cooperation. Technology in marketing and production strengthens community residents by raising income levels, developing occupational skills while developing a space for further sustaining financial, economic, and environmental development. (Office of the National Economics and Social Development Council, 2017)

The result from this international cooperation has created developments in trade and investment. This has required the development of critical infrastructure in land sea, and air transport as well as the development of the crucial border areas connecting Thailand to its neighbours. (Thammasat Institute of Area Studies, 2015) This has affected the adaptation of important economic development strategies of the government in the following ways: the direction of the country's development plans for the Twelfth National Economic and Social Development Plan and the Eastern Economic Corridor (EEC) which is the plan under the strategy of Thailand 4.0 .

\subsection{Eastern Economic Corridor (EEC)}

EEC Development Plan under scheme of Thailand 4.0 aims to revitalize and enhance the success of the Eastern Seaboard Economic Plan; the goal now is to raise the economic zone in the east to a "world-class economic zone" to support Supercluster industrial investment and the country's targeted industries. (Office of the National Economics and Social Development Council, 2017) This calls for investment in fundamental infrastructure and in 10 target industries which complies with Thailand 4.0 strategy. The pilot areas cover three provinces: Chonburi, Rayong, and Chachoengsao. The investment in transport infrastructure constitutes a large portion of the total investment in order to enhance the quality and increase connectivity within the country and the region. (Department of Business Development, 2017) Beyond this, another effect of economic expansion and ties within the region and of sub-regional cooperation is the designation of special economic zones which boosts investment in the country, promotes export, enhances the use of new technology in production of goods, acts as a hub for product 
distribution within the region, increases employment, enhances economic stability and increases the competitiveness of Thai products within the region. The designation of Phase 1 of special economic zones are in the following five provinces: Trat, Tak, Mukdahan, Sa Kaew and Songkhla.

\section{The impact of the local administrative organization toward the economic development}

The economic development is a function of the country's development and the international obligations frame of development. The local administrative organizations may receive the impact of the improvement in many aspects due to the economic policies of the country and the policies of international obligations especially for Asian in three issues as follows.

\subsection{Trading border development}

Trading border means the trade with nearby countries in the same area which connect to Thailand by export and import through the border location officially according to the Ministry of Interior under the Immigration Act B.E. 2522 such as permanent area of border, temporary area, and temporarily permitted area. The development of this area relies on many factors especially trade liberalization under the gathering group of Asean Economic Community or the cooperation of the group of countries CLMV which has policies about reducing trading tax to $0 \%$ after having trade liberalization with six countries. This leads to greater industrial expansion; however, there are still some obstacles such as the road condition in Myanmar, The Lao People's Democratic Republic, and Cambodia which still do not meet the transport standard with a different transporting system and no import transportation agreement. The completion of such an agreement is still the obstacle to trading border with Thailand. (Expert Level Urban and Rural Development Expert, 2015)

According to a study of the trading border development, it was found that Thailand has been trading with 3 countries including Singapore, Southern China, and Vietnam. The trading border of Thailand has increased continuously specially when there is the creation of regional economies operating under the ASEAN frame of liberal trading and the Eastern Economic Corridor and also the Greater Mekong Sub-region development. There is also the aspect of the moving population and products in border areas that connect to nearby countries. The transportation of products has not only the border area as a way for international business, but it also affects the lifestlye of local people in both areas and the basic structural development to support the product transportation through the border areas to other countries. Therefore, the development of the border area is very important and relevent to many segments including the central segment which needs to determinate the policies of development and operation on budget to conduct the border area development. This also includes the area development and the preparation of people. The local administrative organizations in the border area should prepare in many dimensions as will be mentioned.

\subsection{Basic structure development}

For the abovementioned development, Thailand needs to prepare the connectivity and transportation system which can connect to other ASEAN countries. The development of 
transportation network and effective facilities is to increase the convenience of trading, investing, and traveling such as the adjusting the efficiency of trading door so that it can support the transportation of people and products that tend to be increasing especially at the trading border. These are the significant tools to develop the economic border area where it connects between each other to be linked economically to make it more stable and strong. The basic structure development will connect the transportation and import inside the country to support the economic activities, trade, and investment. The development of logistic and import aspects such as import station, transport station, and rest area is needed for convenience and should have international standard. The strategies of the basic structure development in the transportation aspect of Thailand have the following developing frame.

\section{- ASEAN Transport Stategic Plan (ASTP) for 2016-2025}

The cooperation in the domain of transportation in ASEAN aims to support the transport system in the ASEAN region to work effectively and integrate it with the world economy under ASEAN Transport Action Plan 2005-2010 and develop into ASEAN Transport Strategic Plan for 20162025. The cooperation of ASEAN transportation emphasizes on supporting many kinds of transportations, import of product without border areas, and trading liberalization through the ocean and aircraft to facilitate transporting products in ASEAN. Therefore, the agreement frames consist of three books. The objectives are to reduce the procedures in trading process and transporting process in ASEAN. this can be done by creating the ways and agreement together in registering the owner of border trading and other kinds of transportations and support using information technology to transport this without border. (Temtham sitilerd, 2016)

\section{- Master Plan on ASEAN Connectivity}

To conduct the operation in ASEAN to connect every region together has created the Master Plan on ASEAN Connectivity in basic structure, regulations, and population. For the basic structure, the strategy in master plan is having the investment in road construction, railways, sea transport, air transport, and the connection of information technology and gas tube project and electrical line in ASEAN. For regulations, the strategy is determined to facilitate product transportation and services and also immigration by stress on custom service, immigration custom, the prohibition of plants and animals. For population, it is to support tourism. (Economic Division, Department of ASEAN Affairs, 2017)

\section{- The 12th National Economic and Social Development Plan}

Under the strategy of basic structure development and logistic system, the 12th national economic and social development plan has analyzed past circumstances and found that the basic structure development and logistic system encounter on the continuous service and the qualitative and quantitative problems and management are relevant to international standard. It limits developing the country effectively. Hence, the 12th national economic and social development plan determines the strategies on the basic structure development and logistic system to be 4.7 strategy by having the way to improve basic structure by reducing the intensity of using energy and reducing the logistics budget of the country, the development of railways and sea transport, adding more ways of transportation, improving public transport in the city, expanding the limit of handling passengers at Bangkok airport and in surrounding area, and adding a competitive ability in logistics and facilitating trading. For energy development, it should 
increase the ratio between reusing energy and the amount of using last energy and reducing using natural gas to producing electricity, digital development and improving public assistances (water). (Office of the National Economics and Social Development Council, 2017)

The significant ways to develop consist of (1) transportation development such as improving the train system to be the main network for travel and transport in country, road development, air transport development, and sea transport development; (2) supporting improvement in transportation by industrials which come from basic structure investment and improving the management on transportation; (3) logistic development such as improving and upgrading the standard of managing system of logistics and demand chain to meet the international standard and facilitate trading; (4) energy development such as providing reusable and clean energy (5) digital development such as improving digital technology to create business value (6) water supply system to cover all areas and the management of using water effectively and create innovention.

\subsection{Special Economic Zone: SEZ}

Under the economic development after the establishment of ASEAN in 2015, every segment received the impact according to the expansion, economic connection inside the region and cooperation of sub-region level such as Greater Mekong Sub-region (GMS) and The Ayeyawady - Chao Phraya - Mekong Economic Cooperation Strategy (ACMECS). These are the important factors for Thailand that are needed to improve the trading area and investment to support the occured connection. It is in the form of special economic zone which means the area established specially from the laws for supporting and facilitating business and also some privileges on conducting business such as industrial, commercial, administrative or others that benefits the country's economy. Special economic zone has various forms such as trading liberalization area, industrial liberalization area, border trading area and import area.

In this topic, the policy committee of special economic zone has divided the zone into 2 periods for attracting Foreign Direct Investment (FDI) and increasing the country's ability and expanding the growth to rural areas, reducing economic disparity and upgrading the quality of life of people and resolution for security which consist of 4 strategies: 1 . support new economic area; 2 . support basic structure; 3 . support Small and medium-sized enterprises (SMEs) and continue investment and 4. organize economic border area.

As it benefits Thailand where it is the center of the region from special economic zone, it supports investment, export and new production technology, and is the center of products expansion in the region so that it increases employment as it creates economic security and supports the ability for competitive Thai products in the market region. The special economic zone of the first period includes 5 provinces, 6 areas: Trad special economic zone, Tak special economic zone, Mukdahan special economic zone, Sa kaew special economic zone, and Song Khla special economic zone. This is the investment support for special economic zone from the Thai government in the form of privilege of investment and finance which can be divided into 2 cases:

(1) The privilege from the Board of Investment in case of target business and located in special economic zone such as excepting juristic tax for 8 years and is not over $100 \%$ of the invested money excluding lands and circulating budget, reducing net interest from investment 
for $50 \%$ in 5 years from terminated date of excepting juristic tax by deducting transportation, electricity, and water supply for twofold of the cost for 30 years, deducting the investment of installing and constructing the facilities for $25 \%$ of the budget excluding deteriorated time, exempting import duties for machines and materials for import production for 5 years, and allowing alien laborers who do not have the ability in the project to receive support due to the decisions of the Board of Investment.

(2) The privilege from the case of the businesses that do not receive support from the Board of Investment such as deducting the juristic tax for $20 \%$ to $10 \%$ for 10 duration period of account and delaying the debt interest in each 1-20 million baht. Moreover, it has the privilege from Customs Department in case of location in the no duties area and a godown to keep imported goods which do not pay tax yet.

After conducting the economic development in the first period of special economic zone, the second period will cover 5 provinces including Kanchanaburi, Chiang Rai, Nong Kai, Nakhon Phanom, and Naratiwat as the economic expansion with nearby countries. However, the development of special economic zone will acheive their success if there is a need of other aspects of improvement such as the development network on land, sea, air, and railway, the development of customs system and having the modification of basic structure of public assistance and the management inside the special economic zone. It also creates security and strengthens public enterprise of the local area and the business of people in the area.

\section{Analysis and recommendations for the Thai local administrative organization}

Economic development is influenced by domestic development and international obligations. Local administrative organizations may have to bear the effects of various aspects of economic development according to the following four economic policies:

Firstly, the development of border trade zones. The framework for international cooperation in trade and investment leads to border trade with neighboring countries such as Malaysia, Myanmar, Lao PDR and Cambodia with exporting and importing through border points that were officially established along the border of Thailand with neighboring countries by the Ministry of Interior under the Immigration Act which includes 9 borders.

A study found that the development of such border trade affects local commerce within border areas and border mobility tends to rise. Further, traders from neighboring countries cross over to purchase goods and services, largely household items, which causes cash flow in the area to rise. This also affects the livelihood of the locals who shift into trade services-a significant tendency moving from agriculture to commerce. However, the study shows that the increase in border trade investment is largely from external financial sources which affects local enterprises that are yet to be strengthened and established as large businesses.

In this context, local administrative organizations should be prepared to strengthen the community by carrying out community enterprises and to gather local population together through cooperative groups and cooperation between Local administrative organizations in the development of basic infrastructure, including the establishment of economic communities if the locality has the means for production. 
Second, the impact of the development of special economic zones in dimensions regarding local resource utilization. Establishing special economic zones in 5 regions by the central government affects the readiness of the people in the area. In addition, demarcation of various developmental areas entails changes in both labor and urbanization. Though it brings development to the area, it also affects the locals in bearing the burden of the provision of public services in some aspects such as environmental management, waste management, preparation of public health services and social welfare, and the creation of infrastructure to accommodate the changes in the neighborhoods. In the cases referred to, even though the areas designated as special economic zones receive financial support from the state, it does not include the surrounding areas that may be affected by development in order to remedy these adverse effects that may occur.

From the above problems, local administrative organizations should be prepared to assess the impact of waste management, public health operations, and tax measures to collect more local revenue from industries in the special economic zone. In addition, they should consider restructuring administration, particularly within small Local administrative organizations in areas where economic development is prepared to accommodate change.

Third, the development of infrastructure to support economic development. A key factor in supporting economic development is the development of basic infrastructure such as improving the efficiency of commercial channels to accommodate travelers and delivery of goods which is expected to rise; in particular, the development of effective border channels which is considered as an important tool in developing economic regions bordering each other. This will strengthen and stabilize the economy. The development of local infrastructure in relation to travel and transportation will encourage economic activities, trade and investment. Facilities related to transportation and logistics, such as centers for cargo, bus stations, and car rest points should be developed for convenience within global standards. In this respect, though the state allocates funds for the development of basic infrastructure, it is still inadequate for the needs of the citizens and the Local administrative organizations that do not have sufficient budgets to carry out these functions. Because of this issue, the private sector should be encouraged to invest with the local authority (Private Public Partnership) in public services and infrastructure under the purview of local administrative organizations. This is already occurring in many localities such as in solid waste management in the city of Phuket, Patong Municipality, Kra Tu Municipality; or in cases where the locality is given authority to establish a joint venture to develop basic infrastructure e.g. Khon Kaen City Development Limited for preparation of a light rail transit system.

Finally, a local development plan to accommodate progress has to be created. The study found that most of the economic development occurred due to the State's actions which affected the readiness of the locality in connection with development. Therefore, for the locality to be prepared to accommodate these changes, there needs to be a development plan for Local administrative organizations to allow local residents to participate in and review in accordance with the reality of such changes as well as developing cooperation between Local administrative organizations in various ways. 


\section{Acknowledgement}

The paper is a part of a research project "Role and Authority of Local Administration in the Next Decade Regarding Social, Economic and Political Change," Funded by the Thailand Research Fund (TRF), TRF Senior Research Scholar (Professor Dr.Banjerd Singkaneti).

\section{Reference}

U.S.News, 2017. Frequently Asked Questions: 2017 Best Countries. [online] Available at: https://www.usnews.com/news/best-countries/articles/frequently-asked-questions.

Department of Business Development, 2017. Business analysis in the area of special economic development balcony in the eastern region. [online] Available at: http://dbd.go.th/ewt_dl_link.php?nid=469404959.

Economic Division, Department of ASEAN Affairs, 2017. ASEAN Connectivity. [online] Available at: http://www.mfa.go.th/asean/contents/files/other-20170418-114830-829029.pdf

Temtham sitilerd, 2016 . The attractiveness of the ASEAN transport strategy 2011-2015. [online] Available at: http://www.aseanthai.net/ewt_news.php?nid=3852\&filename=index

Thammasat Institute of Area Studies, 2015. GMS: Greater Mekong Subregion.

Office of the National Economics and Social Development Council, 2017. [online] Available at: https://www.thaichamber.org/content/file/document/0714171500000172.pdf

Expert Level Urban and Rural Development Expert Office of the National Economics and Social Development Council, 2015. Border trade and Cross Border with neighboring countries. [online] Available at: http://www.nesdb.go.th/ewt_dl_link.php?nid=6205 